\title{
Construction of Practice Teaching Base for Transportation Specialty on Campus
}

\author{
WANG Jian, SUN Hongtu \\ School of Transportation \\ Ludong University \\ Yantai, CHINA \\ e-mail: wangjdl@163.com
}

\begin{abstract}
Construction of practice teaching base on campus is significant for the training of application-oriented talents. However, the current method for the construction shows the lack of sustainable development performance with the restriction of place, finance, and staff. This paper presents an idea that R\&D (Research and Development) institutes and independent agencies for social services at universities in cooperation with local enterprises could be reconstructed as practice teaching bases on campus to solve the problems of engineering training, scientific training and sustainable development of students. The idea of construction of practice teaching base was verified to be feasible and successful through the practice at Ludong University
\end{abstract}

Keywords-practice teaching base; transportation specialty; campus; Construction

\section{INTRODUCTION}

Practice teaching was a weak part of training talents on higher education with the effect of traditional ideas to focus on theory teaching in despite of practice teaching, the restraint of teaching focus on teacher, class, and textbook, and the difficulty of construction of practice teaching base off campus for many years. Universities paid more attention to practice teaching with the higher requirement of enterprises for qualified graduates. The government gave great financial support for the reform in education and teaching to reach the international level of higher education.

Current practice teaching bases include laboratories, practice teaching bases on campus and off campus. Most experiments of foundational courses, foundational specialty courses and specialty courses are conducted in laboratories. Practice teachings are accomplished at practice teaching bases on campus and off campus. Practice teaching bases are popular due to real working conditions, saving resources for university, promoting cooperation with enterprises, and improvement of teaching in class. In respect of enterprises, students are unacceptable for the concern of daily working, accident, and confidential technology. Students can only perform observation in stead of practice teaching in workshops of practice teaching bases off campus. In respect of universities, the supervise and management for practice teaching are difficult due to few staff and little chance at a same practice teaching base for students. Practice teaching can hardly achieve the expected purpose to improve the quality of practice teaching due to all the problems.

Thus, practice teaching bases on campus tend to be a better choice for convenience supervises flexible time and independent practice teaching to improve the quality of practice teaching [1-13]. This paper presents a new idea for the construction of practice teaching base for transportation specialty on campus.

\section{Characteristics of CURRENT PRACTICE TEACHING BASE CONSTRUCTION ON CAMPUS}

The characteristics of practice teaching base construction on campus are different according to levels and subjects of universities. The classifications of higher education are national key universities, local general universities, and higher vocational colleges or independent schools. Practice teaching base should be constructed according to the orientation and purpose of talents training.

National key universities present to be research-oriented universities for training high level and qualified creative talents. These universities have completed layout of subjects, great social effect, sufficient financial support from nation and social. The practice teaching base on campus was well constructed with comprehensive training, disciplines crossing, creative research, high level, and independent operating for creative talents training.

Local general universities had a confused experience of development once. It was so difficult to keep up with the level of key universities due to the restrained resources and financial supports. The higher level and degree authority were attractive for general universities at the same time of focusing on the foundation and teaching. The orientation and purpose were uncertain to block the development of general universities. Recently, the orientation and purpose were clear with the policy adjustment of nation, the guide of local government, the pressure of employment, experience of talents training, and rationalization of ideas. Local general universities should be application-oriented higher education for application-oriented talents training. Practice teaching base construction so obtained more attention at applicationoriented universities. The international advanced experiences were learned to construct practice teaching base for international level [2]. Some practice teaching bases on campus were improved by integration, renovation, and enrichment for the teaching platform of practice teaching [35]. Production processes and lines were simulated on practice teaching base which were constructed by universities [6] or in cooperation with enterprises [7]. Some practice teaching bases on campus were constructed with the combination of horticulture specialty and landscape on campus [8]. All these bases on campus tend to simulate real 
facilities for practice teaching avoiding dangerous conditions at real workshops.

Higher vocational colleges or independent schools play a role of training application-oriented talents of high qualified laborers and technicians $[9,10]$. They pay more attention to improve practical abilities of students. Many resources were invested into the construction of practice teaching base on campus to train specialty skills of students. Real workshops on campus were simulated at the laboratories on practice teaching bases of some higher vocational colleges [11]. More practice teaching bases with real manufacturing ability were constructed on campus according to the idea of which "the real workshops of enterprises on campus were constructed at the place which was provide by the colleges" $[12,13]$. The practice teaching bases of independent schools on campus could be arranged at the beginning of school foundation due to their new locations for constructions. The function and layout could be optimized for practice teaching bases [14]. The combination of practical train base on campus and off campus made the advantages of correlation of the specialties in colleges and productions of the enterprises to train the engineering application abilities of students.

The foundation and condition of practice teaching base on campus are different according to the division of disciplines in universities. Some practice teaching bases on campus were well improved by the integration, renovation, and enrichment of the old bases which had good foundation before. For example, practical farm at university of agriculture and forestry, affiliated hospital at medical university, affiliated school at normal university, metalworking workshop at university with mechanical specialty, these practice teaching bases could be well constructed without the problem of place. However, most specialties would meet the problem of place for practice teaching bases such as transportation, naval architecture and ocean engineering, electrical engineering and automation, and petrochemical engineering.

\section{REstraint FACtORS OF PRACTICE TEACHING BASE CONSTRUCTION ON CAMPUS}

\section{A. Place}

There are more than 50 specialties in a university according to the present scale of higher education. If $1 / 3$ of the specialties constructed practice teaching bases on campus according to the idea of which "the real workshops of enterprises on campus were constructed at the place which was provided by the colleges", university would turn into a factory with workshops everywhere. This idea could not be popularized under the circumstances of limit areas for most universities.

\section{B. Finance}

Practice teaching base construction required big investment for infrastructure construction, facilities purchasing, installing, debugging, and maintaining. The simulation of production line decreased the cost and place of practice teaching base. However, the limited results and profitless production constrained the further improvement and sustainable development of the practice teaching base. Generally, a high-tech device needs $10 \%$ of the price for maintaining costs [1] which are unacceptable for most universities.

\section{Staff}

Most universities were short of permanent staff for full time job on practice teaching base due to the personnel policy on the restriction of low academic diplomas. The job on practice teaching base was unattractive to the staff with high academic diplomas for higher promotion and salary. The normal operation of practice teaching base was disturbed severely by the staff problem.

\section{Discussion of Practice Teaching Base}

CONSTRUCTION AT LOCAL GENERAL UNIVERSITIES

The orientation and purpose of local general universities are application-oriented universities for training of application-oriented talents. Students should comprehend and apply the knowledge and theory instead of thinking the antecedent and evidence of that. Practical abilities need to be improved with understanding the reason for that. To adapt to the training of application-oriented talent, most of scientific researches are developed around the service for local economy and social at local general universities in cooperation with local enterprises. As the global financial crisis spreading, enterprises realize that it is so urgent for changing the economic growth pattern and adjusting industrial structure. Research and development (R\&D) institutes are established enthusiastically by enterprises in cooperation with local universities. Universities need the creative achievement produced by $R \& D$ institutes with the design at the university and manufacture at the enterprises. Teachers at the $R \& D$ institutes develop productions according to their scientific abilities for the promotion of academic level and profession. Enterprises provide the daily costs for R\&D institutes for more profits and sustainable development.

R\&D institutes play a positive role on training of application-oriented talents. Firstly, scientific researches at R\&D institutes are consistent with training of applicationoriented talents. Design is main part of work during development of production. Creative abilities and technical skills of students in general universities are shown unnecessarily in development of production. The students should be a engineer on the spot for design of production. Secondly, it is appropriate for practice teaching of students that real production was designed during development of production at $\mathrm{R} \& \mathrm{D}$ institutes. Real productions designed at R\&D institutes need to be industrialization by enterprises for profit. Practical abilities of students are improved during development, test, process, and industrialization for production. Thirdly, students are supervised by the staff who have rich experiences on production design at $R \& D$ institutes. The staffs are engineers from enterprises who have rich practical experiences and teachers from universities who have high theoretical level. Knowledge exchanging of them improves practical abilities of teachers and theoretical level of engineers meanwhile. Comprehensive practical abilities of 
students are improved with engineering training and scientific training.

Agreement of practice teaching base should be signed for the duties of universities and enterprises at the beginning of establishment of R\&D institutes. Place, regulation, safety and confidential instruction for practice teaching of students would be arranged during construction of R\&D institutes for normal operation of R\&D institutes and function of practice teaching bases.

Independent agencies for social services at universities are also qualified practice teaching bases. High-tech services are provided by the independent agencies with small places at universities. The services are application-oriented and practical with the specialty of teachers in the agencies for payment which is attractive for talents.

These kinds of practice teaching bases on campus solve the problems of place, finance, and staff for normal operation and sustainable development of practice teaching.

\section{Case study of Practice Teaching Base CONSTRUCTION ON CAMPUS}

Ludong University is a comprehensive province university. School of Transportation has bachelor degrees of transportation, logistics engineering, mechanical design and automation, and naval architecture and ocean engineering. Transportation specialty is a characterized specialty attached to vehicle operation engineering of province key discipline.

Ludong University is located at Yantai, Shandong. Yantai plays a important role at Bohai economic circle of the national key development with the national strategies of the Yellow River delta high-efficiency ecology economic zone and Shandong Peninsula blue economic zone. Land, marine and air transportations are full equipped for logistics in Yantai. The purpose of transportation specialty at Ludong University is to train application-oriented talents of transportation for local economic construction based on Yantai, faced to Shandong, and radiated across the country. The curricular system is transportation course with supplementary courses of new energy vehicle operation, intelligent transportation, and automatic loading device.

$R \& D$ institutes and independent agencies at School of Transportation, Ludong University performs production development, social services, and practice teaching base at the same time. Yantai Institute of Robert and Automation Equipment were founded by School of Transportation in cooperation with Yantai Towin Co., Ltd. for scientific research of industrial robots and practice teaching of automatic loading. Shandong Institute of New Energy Vehicle was founded by School of Transportation in cooperation with Shandong Changyun Group for research of electrical vehicle and practice teaching of new energy vehicle operation. Yantai Institute of Energy and Power was founded by School of Transportation in cooperation with Shandong Ludong Xinneng Technology Co., Ltd. for research of energy saving and practice teaching of engineering. Application of Traffic Accident Judicial Expertise Institute of Ludong University as a independent agency is processed for social services of traffic accident and practice teaching of intelligent transportation. Ludong
University Metalworking Training Institute was founded by School of Transportation in cooperation with Yantai Xigema Precise Pneumatic Hydraulic Engineering Co., Ltd. for production of hydraulic cylinder and practice teaching of metalworking.

The institutes and agencies consisting of teachers from universities and engineers from enterprises are practical for social services with the satisfaction of enterprises. The scientific research and production development are also attractive to students who can also take some part-time jobs for their practical abilities.

\section{CONCLUSIONS}

Practice teaching is significant for the applicationoriented talents training at local general universities. Platforms of practice teaching include laboratories, practice teaching bases on campus and off campus. Duties of laboratories are mainly basic experiments and specialized experiments. Practice teaching bases off campus are ineffective with some problems. Practice teaching bases on campus can be constructed on R\&D institutes or independent agencies of social services instead of simulation of production line or real workshops of enterprises. This kind of practice teaching bases are in accordance to the purpose of application-oriented talents training with sustainable development and extensive prospect.

\section{ACKNOWLEDGMENT}

This work is supported by Comprehensive Pilot Reform of Specialties for Higher Education project.

\section{REFERENCES}

[1] T. Wang and H. Li, "Setting up the Top-ranking Practical Education Center in the World", Research and Exploration in Laboratory, vol. 24, 2005, pp. 1-5, doi:1006-7167(2005)S-0001-05.

[2] H. Zhang, "A Study of Practice Program of Electrification \& Information Engineering Specialty in Applied Science Universities”, Journal of Nanjing Institute of Technology (Social Science Edition),vol. 4, Dec. 2004, pp. 59-64, doi:1671-3753(2004)04-005906.

[3] Y. Xing and G. Zhang, "A Study on Cultivating of Engineering Practice Ability of the Mechanical Engineering specialty", Mechanical Management and Development, vol. 25, Aug. 2010, pp. 176-177, doi:1003-773X(2010)04-0176-02.

[4] S. Chen, N. Guo, "Research and Practice of Optimization and Integration of Practice-Education Base within Campus in Mechanical Specialty”, Scientific Square, vol. 2, 2008, pp. 156-157, doi:16714792(2008)2-0156-02.

[5] J. Bi, J. Zhong, B. Ye, J. Wang and X. Song, "Strengthening insideschool practical teaching bases to improve the students' creative ability”, Laboratory Science, vol. 6, Dec. 2009, pp. 170-172, doi:1672-4305(2009)06-0170-03.

[6] X. Fan, Y. Gao and R. Dang, "Study on Building Intramural Chemical Training Base in Yulin University”, Journal of Yulin University, vol. 21, Mar. 2011, pp. 50-52, doi:1008-2219(2008)060192-03.

[7] X. Han, Y. Zhang, "Exploration and practice of jointly establishing internal practice teaching base by university and enterprise”, Journal of Shenyang Institute of Engineering (Social Science Edition), vol. 6, Apr. 2010, pp. 243-245, doi:1672-9617(2010)02-0243-03.

[8] Y. Wang, L. Chen and X. Yang, "Construction of practice teaching base for landscape specialty on new undergraduate university", 
Journal of Hunan University of Science and Engineering, vol. 29, Jun. 2008, pp. 192-194, doi:1673-2219(2008)06-0192-03.

[9] S. Wu and J. Niu, "Running orientation of high vocational school", Research of Continuing Education, vol. 9, 2011, pp. 47-49, doi:10094156(2011)09-047-03.

[10] G. Liu and Y. Zhang, "Running Location of Independent school", Journal of Jiangxi University of Finance and Economic, vol. 6, 2006, pp. 118-120, doi:1008-2972(2006)06-0118-03.

[11] S. Xu, "Thoughts on ways to cultivate talents in vocational colleges", Journal of Changchun University of Science and Technology, vol. 2, 2006, pp. 4-7.

[12] S. Tan, "On Construction of In-school Base for Practical Teaching in Vocational Colleges in Mode of Work-Study Combination”, Theory and Practice of Education, vol. 30, 2010, pp. 23-25, doi:1004633X(2010)07-0023-03.
[13] Y. Li, H. Liu and J. Mao, "Current condition and strategy of construction of practice teaching base on high vocational school", Journal of Jiangsu Insittute of Education (Natural Science), vol. 26, Feb. 2010, pp. 87-90, doi:1671-1696(2010)02-0087-04.

[14] L. Feng, R. Liu, H. Dong and Y. Wu, "Setting Up Campus Comprehensive Engineering Practice Teaching Base by Means of Resources Integration”, Journal of Hebei Nomal University of Science and Technology, vol. 22, Jun. 2008, pp. 66-70, doi:16727983(2008)02-0066-05.

[15] Y. Zhao, L. Man and Z. Cui, "Construction of practice teaching base for culturing students' ability of engineering application”, Modern Education Science, vol. 3, 2008, pp. 144-146, doi:10055843(2008)03-0144-03.

[16] Y. Li, H. Yang, "On reasonable orientation of local higher intitutions and its impact factors", Journal of Henan Institute of Science and Technology, vol. 2, Oct. 2011, pp. 36-38, doi:1673-6060(2011)100036-03. 